\title{
Persembahan untuk Masa Depan Pengungsi: Resensi Buku
}

\section{Arief Bakhtiar Darmawan}

Universitas Jenderal Soedirman

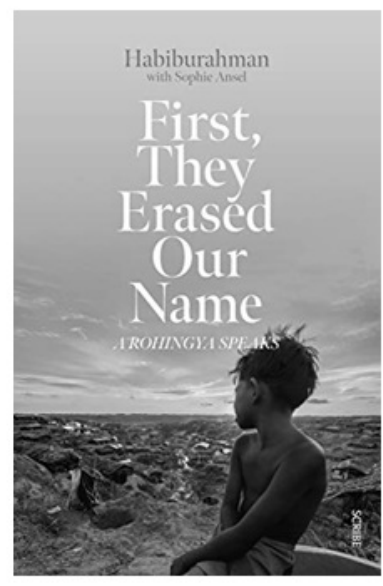

$\begin{array}{ll}\text { Judul } & : \text { First, They Erased Our } \\ \text { Name } & : \text { A Rohingya Speaks } \\ \text { Penulis } & : \text { Habiburahman, Sophia Ansel } \\ \text { Penerbit } & : \text { Scribe UK } \\ \text { Cetakan } & : 2019 \\ \text { Tebal } & : 256 \text { halaman }\end{array}$

"You can say that you are a Muslim. But if you say that you are Rohingya, they will lock you away and then kill you."

(Habib's Dad)

Dalam sepuluh tahun terakhir, menurut laporan United Nations High Commissioner for Refugees (UNHCR), hampir 100 juta orang dipaksa untuk meninggalkan tanah air mereka. Pada tahun 2010, pengungsi terbesar berasal dari Afghanistan (diperkirakan berjumlah 3.054.700 orang) dan Irak (1.683.600 orang). Hampir sepuluh tahun kemudian, akhir tahun 2019, jumlah pengungsi terbesar bergeser, kali ini berasal dari Suriah (6.617.000 orang) dan Venezuela (3.675.500 orang) (UNHCR, 2020: 20). Suriah dan Venezuela memiliki latar masalah yang berbeda. Suriah mengalami perang sipil yang tak kunjung usai, sementara Venezuela mengalami krisis ekonomi yang cukup parah. Orang-orang terpaksa pergi untuk bertahan hidup.

Dari tahun 2011 sampai 2019, jumlah pengungsi terus meningkat secara drastis. Padahal, dari 2000 sampai 2010, jumlah pengungsi cukup stagnan dan mengalami naik-turun (UNHCR, 2020: 7). Meningkatnya jumlah pengungsi membuat para tokoh dunia, mulai dari aktor, penulis, sampai pebisnis, memberi perhatian soal ini. Penulis fiksi Neil Gaiman 
(2018) menulis dalam Sky News bahwa kita harus memperlakukan para pengungsi sebagaimana apa yang kita inginkan ketika kita berada pada posisi mereka. Dalam dunia yang rapuh ini, menurut Neil, siapa saja sangat mungkin menjadi pengungsi, termasuk diri kita. Dalam majalah The Economist edisi khusus The World in 2019, aktor Angelina Jolie (2018: 85) menyatakan bahwa kita harus mendekati persoalan ini melalui argumen kemanusiaan dan meninggalkan debat politik yang memanfaatkan kekhawatiran kita soal pengungsi. Di tahun yang sama, sastrawan besar dunia Khaled Hosseini menerbitkan buku puisi tentang pengungsi yang berjudul Sea Prayer. Bahkan pebisnis dunia Bill Gates pun sempat menyoroti persoalan pengungsi dengan pendapat bahwa Amerika Serikat seharusnya bisa menerima lebih banyak pengungsi seperti yang telah dilakukan oleh Kanada atau Jerman (Miller, 2016).

Berangkat dari isu pengungsi yang semakin relevan, buku First, They Erased Our Name: A Rohingya Speaks yang ditulis Habiburahman dan Sophia Ansel menawarkan pengetahuan dari sisi perjalanan hidup korban. Cerita ini penting sebab kemiskinan, tingkat literasi rendah, dan akses teknologi yang terbatas membuat etnis Rohingya tidak mampu menghadapi penggiringan opini tentang isu Rohingya versi pemerintah Myanmar. Bersamaan dengan itu, selama ini, eksistensi kelompok minoritas sangat bergantung pada pihak lain, seperti para aktivis maupun organisasi internasional yang menyuarakan hak asasi manusia. Habiburahman ingin mendobrak semua itu. Kehadiran buku ini menegaskan: saatnya perspektif dan pengalaman seorang Rohingya berbicara kepada khalayak masyarakat global tentang apa yang sebenarnya terjadi terhadap mereka.

Tokoh utama cerita ini, Habib, menghabiskan masa kecilnya di Desa Mylmin, yang terletak di tepian Sungai Kaladan dan dikelilingi pegunungan tinggi. Desa Mylmin berada di antara Negara Bagian Arakan dan Chin. Penduduk di wilayah Mylmin memiliki identitas yang beragam, mulai dari Kristen, animisme, Muslim, dan Buddha. Kelompok Khumis yang memiliki kepercayaan animisme merupakan penduduk mayoritas, sementara Muslim Rohingnya menjadi minoritas yang hanya terdiri dari sekitar dua puluh keluarga (hal. 13-14). Setiap hari Habib dan etnis Rohingnya mengalami pengalaman rasis. Pengalaman kakek-nenek dan orangtua Habib di masa lalu membuat orang-orang Rohingya tak berani menunjukkan jati diri mereka secara terbuka di masyarakat. Habib menulis:

"The word 'Rohingya' is forbidden. We only use it among ourselves in the hut. It is our secret identity. Dad insists that we use the term 'Muslim' when we introduce ourselves. If we say that we are Rohingya, we would be signing the family's death warrant, he says. So we never do.

For me and Babuli, the word 'Rohingya' evokes hidden danger but also immense pride..." (hal. 13) 
Dari Desa Mylmin, Habib dan keluarganya pindah keNew Thatkaybyin karena rumahnya diambil paksa oleh negara. Seusai menempuh pendidikan sekolah menengah di Sittwe, Habib pergi ke Mangdauw di bagian utara Arakan. Ia berharap mendapatkan pekerjaan di organisasi humanitarian internasional. Tiga bulan di Mangdauw, tak ada kemajuan yang berarti. Habib kemudian pergi ke Yangon setelah mendapat kabar dari ayahnya bahwa ia diterima di sekolah elektro di Irrawaddy. Di Yangon, dengan menyuap, ia membuat kartu identitas baru yang menunjukkan bahwa ia berasal dari Negara Bagian Shan. Nasibnya tak berlangsung begitu baik karena ia memutuskan masuk ke dunia pergerakan menuntut demokrasi di Myanmar. Ia ditangkap polisi Myanmar dan dijebloskan ke penjara.

Habib dan rekannya yang lain bisa bebas dari penjara dengan pertolongan dosennya. Ia diminta secepat mungkin meninggalkan Myanmar melalui perbatasan Myanmar-Thailand di Negara Bagian Shan. Pada awal tahun 2000, ia bertahan di Bangkok bersama satu imigran Rohingya lainnya. Tak lama kemudian, Habib memutuskan pergi ke Malaysia. Di sana, pada tahun 2001, Habib dan beberapa imigran Rohingya mendapatkan dokumen status pengungsi dari UNHCR. Namun dokumen itu ternyata tidak menjamin apa pun. Habib sempat ditangkap oleh petugas imigrasi Malaysia dan Thailand, kemudian dijual ke agen perdagangan manusia. Ia sempat menjadi budak kapal penangkap ikan di Laut Andaman. Habib akhirnya berhasil melarikan diri ketika kapal merapat ke pelabuhan. Ia kembali ke Kuala Lumpur, dan di sana Habib membangun jaringan dengan para aktivis dan komunitas internasional. Karena dianggap berbahaya, Habib terus menjadi target dari pasukan keamanan Malaysia. Ketika situasi semakin mendesak, Habib dan beberapa etnis Rohingya memutusan melarikan diri ke Australia. Kapalnya ditemukan oleh patroli keamanan laut Australia, dan Habib dibawa ke penjara imigran di Darwin. Dengan fasilitas dan akses internet di penjara itulah, Habib bisa leluasa menulis dan menghubungi jurnalis maupun aktivis organisasi internasional mengenai nasib etnis Rohingya.

Sejak semula, kita akan mengetahui bahwa model kolaborasi dan gaya bercerita Habiburahman dan Sophia Ansel dalam buku First, They Erased Our Name: A Rohingya Speaks sama seperti Malala Yousafzai (yang berkolaborasi bersama Christina Lamb) dalam I Am Malala: The Story of the Girl Who Stood Up for Education and was Shot by the Taliban yang diterbitkan pada 2013 oleh Weidenfeld \& Nicolson di Inggris dan Little, Brown and Company di Amerika Serikat. Buku lain dengan model kolaborasi yang sama adalah The Raqqa Diaries: Escape from Islamic State, diterbitkan pada 2017 oleh Hutchinson. Buku The Raqqa Diaries sendiri menceritakan kisah seorang pemuda bernama samaran Samer, yang ditulis ulang oleh Mike Thomson. Cerita di kedua buku tersebut merupakan adopsi lain dari program siaran radio berseri dari BBC. Dalam ketiga buku tersebut, penulis sebagai tokoh utama cerita menggunakan kata ganti orang pertama "Aku", yang mengisahkan pengalaman hidupnya sesuai dengan urutan waktu kejadian. 
Dalam buku ini, Habib memulai dari kebijakan pemerintah Myanmar di bawah Jenderal U Ne Win. Ne Win merupakan jenderal yang berkuasa dari tahun 1962 sampai 1988. Ne Win berkuasa setelah melakukan kudeta terhadap U Nu, dan selanjutnya memimpin Myanmar secara otoriter. Pada tahun 1964, Ne Win membuat Myanmar hanya memiliki satu partai sosialis, yang berada di bawah kekuasaan Ne Win dan para pejabat militer. Pada tahun 1982, Ne Win mengeluarkan hukum kewarganegaraan Myanmar berdasarkan ras tertentu. Persoalannya, menurut hukum baru tersebut, etnis Rohingnya tidak termasuk dan tidak dianggap sebagai ras asli Myanmar. Mereka dianggap sebagai orang-orang Bengali yang melakukan invasi ke Myanmar di masa lalu, dan sekarang harus pergi dari Myanmar. Saat kebijakan itu keluar, Habib masih berusia tiga tahun. Dari situlah pelarian demi pelarian etnis Rohingya bermula.

Menarik bahwa cerita-cerita di dunia sekitar Habib saling berkelindan dengan dunia perpolitikan Myanmar. Pada halaman 29, Habib bercerita bahwa demonstrasi besar-besaran pada tahun 1988 sempat memunculkan sebuah harapan pergantian rezim dan kebijakan. Pada tahun tersebut, demonstrasi terhadap rezim diktator Myanmar terjadi di mana-mana, termasuk di pedalaman Mylmin. Orang Rohingya, Khumis, Bamars, dan Rahkine beramai-ramai turun ke jalan menuntut kebebasan. Namun, tak berapa lama demonstrasi berhasil dipadamkan melalui kekerasan dan teror oleh militer. Kebijakan perpolitikan Myanmar kembali diceritakan Habib pada halaman 67. Pada tahun 1991, pemerintah Myanmar melakukan operasi yang diberi nama Clean and Beautiful Nation. Implementasi operasi tersebut tidak jauh berbeda dengan kebijakan sebelumnya: perburuan dan pembantaian etnis minoritas yang diberi embel-embel nama yang indah dan puitis. Akibat operasi tersebut, ribuan orang Rohingya terpaksa melarikan diri ke Bangladesh, sementara tempat tinggal mereka dibakar atau diubah menjadi pemukiman etnis-etnis beragama Buddha yang selama ini mendapat keistimewaan di Myanmar.

Salah satu persamaan penting dariHabiburahman dengan cerita Malala dan Samer adalah memiliki orang tua yang sama-sama mementingkan pendidikan. Dalam kasus Malala, ayahnya adalah seorang guru yang bangga jika putrinya, seorang perempuan, menempuh pendidikan setinggi mungkin. Dalam kasus Habib, ayahnya tidak ingin Habib menjadi seperti orang Rohingya kebanyakan. Ayahnya percaya pendidikan akan menjadi kunci keberhasilan di masa depan:

"I want you to be as educated as possible. It's for your own good. It will save your life sooner than you think." (hal. 18)

"If you want to be grown-up, you'll have to stop constantly thinking about playing. You have to study if you want to avoid the fate that the Burmese regime has chosen fo us. Education is the key of emancipation." (hal. 19)

Di New Thatkaybyin, ayahnya menyekolahkan Habib di sekolah 
negeri agar mendapatkan kualitas pendidikan yang setara dengan anakanak Myanmar pada umumnya. Meski biaya sekolah negeri lebih mahal dari sekolah Islam dan resiko mendapatkan perlakukan buruk sangat tinggi, ayahnya tetap mengirim Habib ke sana. Setelah lulus sekolah menengah, Habib berhasil menempuh pendidikan universitas di Irrawaddy, sampai kemudian ditangkap junta karena terlibat pergerakan menuntut demokrasi. Setelah berhasil lolos, perjalanan pelarian Habib berlanjut ke luar negeri, sampai saat ini.

Kemampuan media untuk menggiring opini negatif terhadap etnis minoritas, imigran, atau pengungsi, bukan lah hal yang baru. Di dalam negeri, pemerintah Myanmar berhasil menanamkan imej buruk terhadap etnis Rohingya. Dari kisah perjalanan hidup Habib, kita bisa mengamati bahwa interaksi antara tiga komponen utama, yaitu media, kebijakan pemerintah, dan sikap publik, berjalan menuju arah yang sama dalam memojokkan etnis Rohingya. Menandingi tiga unsur tersebut rasanya mustahil bagi seorang Rohingya. Namun, di situ lah letak kelebihan buku ini, yaitu kepercayaan diri Habiburahman untuk menandingi satu suara oposisi dari Myanmar yang sempat dipercaya oleh masyarakat global: Aung San Suu Kyi. Aung San Suu Kyi merupakah tokoh hak asasi manusia Myanmar yang menerima Nobel Perdamaian tahun 2012. Suu Kyi juga menerima sederet penghargaan lainnya, seperti dari Amnesty International, US Holocaust Memorial Museum, serta Oxford University. Pada tahun 2018, penghargaan dari ketiga institusi dicabut karena Aung San Suu Kyi dianggap tidak lagi mewakili simbol keberanian dalam membela hak asasi manusia.

Buku yang ditulis seperti novel biografi ini memudahkan masyarakat umum, yang mungkin tidak familiar dengan isu-isu hubungan internasional, untuk memahami secara garis besar bagaimana para pengungsi berjuang dalam kehidupan mereka. Memang cerita Habib tidak selamanya berisi penderitaan. Habib kecil pernah merasakan kebahagiaan ketika bermain bersama kawannya yang seorang Kristen, atau ketika berlatih sepak bola bersama kawan dari etnis lainnya.

Kalangan akademis perlu membaca buku ini untuk memperkaya sumber referensi pengalaman pengungsi Rohingya karena orang-orang dari etnis Rohingya, setidaknya sampai saat ini, tidak ada yang menjadi akademis dan menulis karya ilmiah di jurnal internasional. Etnis Rohingya, seperti kata Habib, "tidak pernah menulis sejarah mereka sendiri". Kewarganegaraan mereka yang tidak diakui membuat etnis Rohingya kesulitan menempuh pendidikan tinggi, seperti yang dialami Habib ketika ingin mendaftar kuliah di Malaysia. Meski bukan buku akademis, buku ini bisa menambah pengetahuan kita terhadap persoalan-persoalan hubungan internasional seperti imigrasi atau kejahatan transnasional dari sisi kehidupan yang paling dasar. Dari sisi yang lain, kita melihat bahwa negara tidak selalu benar. Tidak ada kebenaran tunggal yang absolut, termasuk monopoli kebenaran oleh entitas bernama negara. Pertanyaannya: 
apakah kita perlu mengambil sikap tidak nasionalis? Penulis sendiri tidak akan mengambil kesimpulan itu. Yang jelas, kita selalu yakin untuk terus memihak korban.

\section{Daftar Pustaka}

Jolie, A. (2018). How to Alleviate the Refugee Crisis. The Economist, 7 November.

Gaiman, N. (2018). We Must Help Refugees Because, 'Simply, It Could Be You' [Online]. 9 Juli. Tersedia di: <https://news.sky.com/story/ we-must-help-refugees-because-simply-it-could-be-you-11410452> [diakses 21 Juli 2021].

Gayatri, S.D., \& Januardy, A.F. (2018). Knocking on Closed Doors: Refugees in ASEAN [Online]. 29 Maret. Tersedia di: <http://www.thejakartapost. com/academia/2018/03/29/knocking-on-closed-doors-refugees-inasean.html> [diakses 21 Juli 2021].

Miller, J. (2016). Bill Gates: US 'Should Take More' Refugees [Online]. 22 Januari. Tersedia di: <https://www.bbc.com/news/business-35381129> [diakses 21 Juli 2021].

United Nations High Commissioner for Refugees. (2020). Global Trends: Forced Displacement in 2019. Copenhagen. 